\title{
MODELING OF THE MONITORING SYSTEM OF LEARNING OUTCOMES IN ADULT EDUCATION
}

\author{
Svetlana Nevdakh \\ Belarusian State Pedagogical University named after Maxim Tank, \\ Republic of Belarus
}

\begin{abstract}
In recent years, the need has arisen for a change in conceptual approaches to the phenomena of "monitoring" and "assessment" of learning outcomes in adult education. The ultimate goal of monitoring should be to strengthen and achieve a high level of responsibility of the learners for the process and outcomes of their education. The purpose of the research is to create a model of the monitoring system of learning outcomes in adult education and to describe a methodology for implementing alternative methods of monitoring. Research methods: a theoretical analysis of the concept of "monitoring", generalization and systematization of approaches to monitoring, analysis of the characteristics of adult education, modeling of the monitoring system of learning outcomes in adult education, ranging monitoring types by teachers, analysis of the results of the empirical research. The main results of the research: a model of the monitoring system of-learning outcomes in adult education includes preparatory, practical and analytical stages and it is built taking into account the purpose, content, methods of pedagogical communication, means, timing and duration of control. It also includes traditional and alternative ways of monitoring learning outcomes with guidelines for their use in adult education.
\end{abstract}

Keywords: adult education, learning outcomes, monitoring, modeling, adult learners.

\section{Introduction}

Testing and assessment the quality of learners' training is an integral part of the educational process in adult education. Modern requirements for the quality of training of specialists necessitate a review of existing methods for assessing learning outcomes, updating the training technologies used in teaching practice, as well as designing and introducing new ones. Monitoring of learning outcomes as a component of learning activity permeates all stages of the educational process. There are two main approaches to the problem of monitoring learning outcomes. The first, traditional, interprets the learning outcomes as an increase in knowledge and skills of learners. The second approach is based on the recognition of the need to take into account the dynamics of personal development. Unfortunately, the traditional approach to monitoring learning outcomes tends to dominate in the education system. 
In recent years, the need has arisen for a change in conceptual approaches to the phenomena of "monitoring" and "assessment" of learning outcomes in adult education. The ultimate goal of monitoring should be to strengthen and achieve a high level of responsibility of adult learners for the process and result of their education. The purpose of the research is to create a model of the monitoring system of learning outcomes in adult education and to describe a methodology for implementing alternative methods of monitoring. Research methods: a theoretical analysis of the concept of "monitoring”, generalization and systematization of approaches to monitoring, analysis of the characteristics of adult education, modeling of the monitoring system of learning outcomes in adult education, ranging monitoring types by teachers, analysis of the results of an empirical research. The main results of the research: a model of the monitoring system of learning outcomes in adult education includes preparatory, practical and analytical stages and it is built taking into account the purpose, content, and methods of pedagogical communication, means, timing and duration of control. It also includes traditional and alternative ways of monitoring learning outcomes with guidelines for their use in adult education.

\section{Literature review}

The problem of monitoring and assessment the learning outcomes of learners is widely represented in the psychological and pedagogical literature. Its various aspects are investigated: the essence, the role of monitoring and assessment, the structure of the teacher's assessment activity, the advantages and disadvantages of the point system, etc. (Khutorskoy, 2007; Kraevsky \& Khutorskoy, 2007). However, today many unresolved issues remain, in particular, monitoring of the learning outcomes of adult learners. Against the background of a large number of studies of teachers' assessment and evaluative activities, the question of rethinking the system of monitoring and assessment of learning outcomes in adult education attracts much less attention of researchers.

Learning in adult education is to ensure adult learners to master the activity structure they are engaged in, which starts from awareness of its motives and purpose until the results are obtained, and which comprises the adult learners' capability to assess and adjust the undertaken course of action based upon the reflection.

An adult learner is a subject with self-consciousness and independence inherent in him insofar as he assimilates a certain amount of culture, methods of professional activity, forms of cultural interaction with people and he is aware of his human nature. In the process of training in adult education, it is necessary to help learners realize the prospects for professional and personal growth; to create a situation of interpersonal interaction in the course of training; provide 
each listener with the opportunity to express and assert themselves through the presentation of their positive experiences; to provide real progress in the development of educational content; to orient the educational process toward obtaining a specific product (project, program of action, technology, etc.) that can be "transferred" to the situation of professional activity.

In adult education, it is important to rely on the natural process of selfdevelopment of abilities and the creative potential of a person (Yakimanskaya, 2000; Serikov, 1994), and also create appropriate conditions for providing:

- $\quad$ pedagogical research of learners to identify knowledge, skills;

- displaying individual professional characteristics;

- development of exemplary professional self-education program by each student (assisted by a teacher);

- organization of the learning process orienting learners on the awareness and adoption of the vocational training goals, mastery of the system of knowledge and skills assigned by the job description;

- $\quad$ a system of independent work of a search and research nature;

- $\quad$ systematic process of monitoring students' competence level;

- the inclusion of learners in various types of practices with the aim of compulsory testing, improvement and tracking the growth of professionalism in the conditions of training in adult education.

Improving the quality of professional training of a future specialist is associated with the creation of conditions for his self-realization. Self-realization is understood as the person's ability to act successfully in a given situation. Education acquired in the course of independent work, as well as in the process of training in adult education, contributes to the formation of a holistic system of knowledge, abilities, skills of a person in a certain field, their purposefulness, activity, justification of motivation, independence, adequacy in decisionmaking, solution responsibility critical evaluating of one's actions (Nevdakh, 2015).

Verification and assessment of the quality of education is an integral part of the adult educational process, the purpose of which is to ensure the training of specialists as the state educational standard required.

Monitoring as a system of evidence-based verification of learning outcomes means the identification, measurement and evaluation of knowledge, skills and abilities of learners (Kraevsky \& Khutorskoy, 2007). At the same time, there is a reason to believe that there is a specificity in assessing educational results with competency-based and personality-oriented approaches to learning. So, the specificity of assessing the results of training focused on the formation of competencies will be manifested in the characteristics of the criteria, which should reflect not only knowledge and methods of action, but 
also the process of activity, as well as, possibly, the activity meanings. The issue is about indicators of ownership of self-organization methods in the educational environment, a culture of thinking.

Assessing personal learning outcomes, it is necessary to create for the listener such situation in which he could show and realize his subjective position (Elkina, 2016).

Assessment of learning outcomes in adult education is a systematic process of correlating the results and the progress of their learning activities with predetermined standards of the educational program. Typically, this is a list of competencies that should be acquired by adult learners.

International trends in education indicate a transition from the traditional approach to the approach presupposing learners' capability to apply knowledge after completion a module or the entire educational program into daily practice. It is called a result-oriented approach.

The origins of a result-oriented approach can be traced back to the United States from the second half of the 20th century. One of the representatives of this type of training is R. Mager, who proposed the idea of developing specific formulations of the observed results and called them educational goals (Mager, 1975). Based on this idea, he tried to determine the type of training, and how this training will be assessed. Later, learning goals transformed into specific learning outcomes.

A result-oriented approach to teaching is gaining international popularity. It is increasingly used in credit systems and is actively used by national quality assurance and qualification bodies, such as the Higher Education Quality Assurance Agency in the United Kingdom (Gosling \& Moon, 2001).

As part of the Bologna process, since 2010 all modules and educational programs in almost all participating countries have been formulated using a results-based approach. However, in some countries of the European Higher Education Area, a competency-based approach is still used in determining results of education.

An analysis of sources on the subject of learning outcomes indicates a commonality of definitions. Learning outcomes, as a rule, are specific formulations of what learners should know and be able to do based on the results of the training (Morss \& Murray, 2005; Jenkins \& Unwin, 2001; European Qualifications Framework; Adam, 2004).

The learning outcomes are focused on what the listener has achieved, and not on the content of what he was taught, and what the listener can demonstrate at the end of the training. This is reflected in the ECTS Guide (2015). Learning outcomes should be stated in a simple and clear language and should include the possibility of a reliable assessment.

The embodiment of the main goals of monitoring is expressed in 
psychological, pedagogical and functional results. Scientists state that new components in the structure of knowledge and training skills, behavior, personality attitude, the system of relationship are referred to psychological and pedagogical results. As for the methods of pedagogical impact, they are referred to functional results.

V. Kalney (2000) and other researchers distinguish the following types of monitoring in the field of education:

- in terms of the scope of educational goals - strategic, tactical, operational;

- $\quad$ at the stages of training - qualifying, intermediate, final;

- $\quad$ time dependence - retrospective, prospective, current;

- $\quad$ by the frequency of the procedures - one-time, periodic, systematic;

- according to the coverage of the object of observation - local, selective, continuous;

- $\quad$ by organizational forms - individual, group, frontal;

- in the forms of subject-object relations - external (social), mutual control, introspection;

- $\quad$ according to the tools used - standardized, non-standardized, matrix (Shishov \& Kalney, 2000).

The main principles of monitoring are:

- representativeness of information (the need to obtain data not only reliable, but also reflecting a really existing range of opinions and assessments of the process of preparing learners in adult education);

- taxonomy of data (the need to use data to compare information received from different subjects of monitoring and use objective criteria for its comparative analysis, systematization and generalization, to identify a hierarchy of factors that determine the effectiveness of the implementation of the adult learning process);

- predictability (the need to obtain data to predict the direction of preparation of adult learners, to identify and analyze social and educational consequences, effects and risks of implementation);

- targeting (the need for targeted monitoring procedures, for the participation of a sufficient number of representatives of those professional groups and interest groups whose position determines the innovative nature of the implementation of the training process for adult learners) (Nevdakh, 2015).

It is well known that monitoring and assessment are the most important tools for motivating learners to learn. Meanwhile, the problem of the objectivity of these processes is one of the most controversial in the theory and practice of education. Despite the achievements, the issue of adequate reflection of the level 
of knowledge and skills of adult learners by marks (points) given by teachers, remains open. The difficulties associated with its solution are determined by the fact that, on the one hand, conceptual provisions determining the nature, structure and mechanisms of monitoring and evaluation are still not well developed; on the other hand, the subjectivity of this process is obvious: there are many teachers, as well as there are many systems and rules presupposing the choice of appropriate grade.

In our opinion, an important point in ensuring the objectivity of assessing learning outcomes in adult education is their involvement in this process. During learning activities including training others the problem of monitoring and evaluating students' educational results is highlighted particularly. The knowledge and skills obtained in the process of training on the organization and content of monitoring and evaluation of educational results allow learners to rethink the features of their professional activities in the direction of a new, deeper understanding of these components of the educational process (Shingirey \& Shilova, 2012). The ultimate goal of assessment in these conditions will be to strengthen and, in the future, to achieve a high level of responsibility of the listener for the process and the result of his education and self-education.

This requires a change in generally accepted approaches to the problem of monitoring and evaluating learning outcomes in adult education. These changes are as follows:

- $\quad$ ensuring the process of subject-subject cooperation;

- $\quad$ shifting from process to result;

- $\quad$ assessment of the breadth and depth of applied (professional and life) knowledge and skills;

- $\quad$ changing the role of the teacher: organizer, counselor, mentor;

- encouraging self-control, self-esteem and mutual evaluation of learners;

- $\quad$ focusing on what the learner knows and can do;

- $\quad$ assessment of the individual achievements of each listener regardless of the achievements of others;

- $\quad$ encouraging individual and group evaluations;

- identification of difficulties and their overcoming in collaboration with the teacher or colleagues;

- $\quad$ creating a comfortable educational environment.

The sense of pedagogical expediency and tact focusing on the learner's development which are expressed in support, a positive assessment, the right level of claims, self-confidence, encouraging higher adult achievement underlie the individual monitoring and evaluation concept of a successful teacher. 
Thus, the quality monitoring system in adult education provides the solution of the following tasks:

- $\quad$ ensuring holistic and complete assimilation by learners of the content of educational programs;

- $\quad$ widespread use of modern monitoring and evaluation technologies;

- $\quad$ organization of independent work of learners, taking into account their individual characteristics.

The solution of these problems necessitated the modeling of a system for monitoring adult learners' outcomes.

Currently, it is impossible to indicate the area of human activity where modeling would not be applied. Being one of the methods of scientific research, modeling is widely used in pedagogy. Modeling is the study of objects of cognition on their models; construction (analysis, study) of models of objects, systems, structures, processes, etc. (Rapatsevich, 2005, p. 323). According to the definition of G. Sukhodolsky, modeling is the process of creating a hierarchy of models in which some real-life system is modeled in various aspects and by various means (Sukhodolsky, 1976).

Modeling is usually associated with the need to study pedagogical processes, their improvement and modernization; testing new approaches to education, innovations that ensure the development of the education system and its institutions, etc.

\section{Methodology}

The modeling of the monitoring system of learning outcomes in adult education in our study was based on the principles of modeling in general and pedagogical modeling in particular. The study involved 27 teachers of the Belarusian State Pedagogical University named after Maxim Tank, who conducted classes with adult learners in the realization of educational programs for continuing education and retraining. They were asked to rank the types of control that were used in adult education. The obtained results served as the basis for the adjustment of the developed model with the goal of maximally approximating it to the real conditions of the educational process in adult education.

\section{Research results}

The system for monitoring adult learners' outcomes was created with the aim of obtaining objective information about the level and quality of learners mastering educational programs for advanced training and retraining. 
The functions that determine the content of monitoring are:

- diagnostic (allows to obtain objective information about the quality of training of adult learners, the quality of teaching, the quality of educational programs of adult education and teaching materials, etc.);

- adaptation-forming (provides the administration and teachers with the information necessary for making managerial decisions, creating conditions for the formation of professional qualities of learners);

- corrective (allows to see the need to adjust problem aspects in the realization of the educational process of training teachers in the system of adult education);

- prognostic (allows to use the information received to make adjustments to the educational process, as well as management decisions).

Assessment of the achievement of planned results is carried out in three groups of educational outcomes: personal, meta-subject and subject:

- $\quad$ objective results (knowledge and skills, experience of creative activity acquired in the process of studying academic disciplines, etc.);

- meta-subject results (methods of activity, developed on the basis of one or several disciplines, applicable both in the framework of the educational process, and when solving problems in real life situations);

- $\quad$ personal results (system of value relationships, motivation, etc.)

Monitoring the learning outcomes of adult learners has several stages: preparatory, practical and analytical.

The preparatory phase is determined by the setting of goals and objectives, the object and subject of research; includes the study of work experience, conducting control measurements, the development of an assessment procedure, the selection of tools.

The practical stage is a diagnostic activity aimed at obtaining information about the studied object or process, identifying potential opportunities for participants' development in the educational process; forecasting the organization of pedagogical interaction; self-study, self-development.

The analytical stage includes processing and systematization, quantitative and qualitative analysis of the information received, generalization and establishment of reasons, factors affecting the nature of the pedagogical process, formulation of conclusions and development of recommendations.

The realization of educational programs for advanced training and retraining is regulated by normative documents. According to these documents, the main forms of monitoring are exam, test, defense of term paper, essay, interview, etc., The competencies are defined in curricula and educational 
standards. And the level of formation of these competencies is the result of training.

In the course of the study, we invited teachers who work with adult learners to rank the types of control. $81 \%$ of respondents completely abandoned the traditional methods of examinations and tests. $74 \%$ - use the potential of such technologies as collaborative teaching, peer learning, simulation games, etc., as the basis of control. 37\% of teachers believe that in some cases, you should not give up a serious survey of adult learners in the ticket exam. However, these tickets must include practice-oriented tasks.

As an alternative way of control, teachers indicated the effectiveness of the interactive technologies: «Minute of Speaking», «Test-learning», «Tournamentquiz», «Only facts», «Boomerang», «Assignment from an envelope», «Recipes of success», etc. In the process of monitoring and evaluating the results of educational achievements, the teacher and learners act as subjects of the educational process. Learners themselves manage their educational activities, as well as independently evaluate the results of their work. The teacher's task is to ensure the personal and professional development of learners which is expressed in self-esteem, level of claims, self-confidence, focus on changes in their professional activities.

\section{Conclusions}

Thus, the monitoring system of learning outcomes in adult education includes preparatory, practical and analytical stages and is built taking into account the purpose, content, methods of pedagogical communication, means, timing and duration of monitoring. It includes traditional and alternative ways of monitoring learning outcomes. The implementation of monitoring and evaluation activities should be aimed at ensuring the possibility of professional development of the personality, realizing its creative potential and shaping the mechanisms of self-development, self-education, spiritual and moral qualities in the process of preparation in adult education.

\section{References}

Adam, S. (2004). Using Learning Outcomes: A consideration of the nature, role, application and implications for European education of employing learning outcomes at the local, national and international levels. Report on United Kingdom Bologna Seminar, July 2004, Herriot-Watt University, Edinburgh.

ECTS Users' Guide. (2015). Brussels: Directorate-General for Education and Culture. Retrieved from https://ec.europa.eu/education/ects/users-guide/docs/ects-users-guide_ en.pdf

EU (European Union) Commission. (2008). European Qualifications Framework for Lifelong 
Nevdakh, 2020. Modeling of the Monitoring System of Learning Outcomes in Adult Education

Learning. Luxembourg: Office for Official Publications of the European Communities.

Gosling, D., \& Moon, J. (2001). How to use Learning Outcomes and Assessment Criteria. London: Southern England Consortium for Credit Accumulation and Transfer (SEec) Office.

Jenkins, A., \& Unwin, D. (2001). How to write learning outcomes. Retrieved from https://www.ubalt.edu/cas/faculty/faculty-matters/How\%20to\%20write\%20Student\% 20learning\%20outcomes.pdf

Mager, R. (1975). Preparing Instructional Objectives. Belmont, California: Fearon Publishers.

Morss, K., \& Murray, M. (2005). Teaching at University. London: Sage Publications.

Elkina, I. (2016). Didakticheskiye osnovaniya otsenivaniya rezul'tatov obucheniya pri sovremennykh pedagogicheskikh podkhodakh. Moskva: FGBNU Institut strategii razvitiya obrazovaniya Rossiyskoy akademii obrazovaniya.

Khutorskoy, A. (2007). Diagnostika i kontrol'v obuchenii. Moskva: Vysshaya shkola.

Kraevsky, V., \& Khutorskoy, A. (2007). Sredstva obucheniya i kontrolya. Iz (V. Kraevsky \& A. Khutorskoy) Osnovy obucheniya. Didaktika i metodika (270-288). Moskva: Akademiya.

Nevdakh, S. (2015). Podgotovka pedagogov v sisteme dopolnitelnogo obrazovaniya vzroslykh $v$ usloviyakh integratsionnykh protsessov. Minsk: Bestprint.

Rapatsevich, E. (2005). Pedagogika: bol'shaya sovremennaya entsiklopediya. Minsk: Sovremennoye slovo.

Serikov, V. (1994). Lichnostnyy podkhod $v$ obrazovanii: kontseptsiya i tekhnologii. Volgograd: Peremena.

Shingirey, T., \& Shilova, E. (2012). Osobennosti kontrolya i otsenivaniya uchebnykh dostizheniy slushateley sistemy dopolnitel'nogo obrazovaniya vzroslykh. Retrieved from http://elib.bspu.by/handle/doc/6700

Shishov, S., \& Kalney, V. (2000). Shkola: monitoring kachestva obrazovaniya. Moskva: Pedagogicheskoye obshchestvo Rossii.

Sukhodolsky, G. (1976). Strukturno-algoritmicheskiy analiz i sintez deyatel'nosti. Leningrad: LGU.

Yakimanskaya, I. (2000). Tekhnologiya lichnostno-oriyentirovannogo obrazovaniya. Moskva: Sentyabr'. 